\title{
PERFORMANCE OF A DIESEL ENGINE FUELED WITH A PREHEATED BLEND OF SOYBEAN OIL AND PETRODIESEL
}

\section{HEVANDRO C. DELALIBERA ${ }^{1}$, NILSON CAMPOLINA ${ }^{2}$, PEDRO H. WEIRICH NETO ${ }^{3}$, RICARDO RALISCH ${ }^{4}$}

\begin{abstract}
Brazil is doing a major effort to find alternatives to diesel oil as combustible. Some study lines are oriented to the development of vegetable oils used as fuel, as a source of getting cheaper and have higher energy density than the converted vegetable oils, and less risk of environmental contamination. The aim of this study was to evaluate the performance, the useful life of the lubricant and some components of a Diesel Cycle engine, with an electronic injection system, in a long-term test operating with a preheated blend $\left(65^{\circ} \mathrm{C}\right)$ of $50 \%\left(\mathrm{v} \mathrm{v}^{-1}\right)$ of soybean oil in petrodiesel. There was a reduction of the useful life of the injectors which presented failure because of high wear with 264 hours of operation and showed an increase in emissions of particulate matter (opacity) which may be assigned to the failures occurred in the injection system. An increase in the useful life of the lubricant, when compared with the literature was also observed. The electronic injection system may favor the burning of the tested fuel. The test was interrupted with 264 hours because of failures in the injection system.
\end{abstract}

KEYWORDS: Electronic injection, opacity, lubricant.

\section{DESEMPENHO DE UM MOTOR DIESEL ALIMENTADO COM UMA MISTURA PRÉ- -AQUECIDA DE ÓLEO DE SOJA E PETRODIESEL}

RESUMO: No Brasil, tem-se notado um grande esforço para encontrar alternativas ao óleo diesel como combustível. Algumas linhas de estudo estão direcionadas ao desenvolvimento dos óleos vegetais para tal fim, por ser uma fonte de obtenção de menor custo e ter densidade energética maior que os óleos vegetais transformados, além de apresentar menor risco de contaminação ambiental. O objetivo deste trabalho foi avaliar o desempenho, a vida útil do lubrificante e de alguns componentes de um motor Ciclo Diesel, com sistema de injeção eletrônica, em um ensaio de longa duração, sendo este alimentado com uma mistura pré-aquecida $\left(65^{\circ} \mathrm{C}\right)$ de $50 \%\left(\mathrm{v} \mathrm{v}^{-1}\right)$ de óleo de soja no petrodiesel. Observou-se redução da vida útil dos injetores que apresentaram falha por desgaste elevado com $264 \mathrm{~h}$ de funcionamento e aumento da emissão de material particulado (opacidade), o que pode ser atribuído às falhas ocorridas no sistema de injeção. Também se observou aumento da vida útil do lubrificante, quando comparado com a bibliografia. O sistema de injeção eletrônica pode favorecer a queima do combustível testado. $\mathrm{O}$ ensaio foi interrompido com $264 \mathrm{~h}$ devido a falhas no sistema de injeção.

PALAVRAS-CHAVE: Injeção eletrônica, opacidade, lubrificante.

\footnotetext{
${ }^{1}$ Pesquisador, Área de Engenharia Agrícola - Instituto Agronômico do Paraná (IAPAR), hevandro@iapar.br.

${ }^{2}$ Coordenador de Manutenção de Frota, Grupo CCR RodoNorte, nilsoncampolina@ig.com.br.

${ }^{3}$ Professor doutor, Departamento de Ciência do Solo e Engenharia Agrícola; Labroratório de Mecanização Agrícola (Lama) -

Universidade Estadual de Ponta Grossa (UEPG), lama1@uepg.br.

${ }^{4}$ Professor doutor, Centro de Ciências Agrárias; Depto. de Agronomia - Universidade Estadual de Londrina (UEL), ralisch@uel.br.

Recebido pelo Conselho Editorial em: 16-1-2012

Aprovado pelo Conselho Editorial em: 21-6-2012
} 


\section{INTRODUCTION}

The growing concern over environmental pollution and the increase in oil prices has driven the development of research in the quest for renewable fuels. Brazil, with technology and developed market for ethanol as a gasoline substitute, is now seeking alternatives to petrodiesel. Currently, vegetable oils and their derivatives are in focus because they have some characteristics similar to petrodiesel. However, the parameters and quality procedures and use, especially for vegetable oils, are not well defined.

Despite being favorable from the point of view of energy, the direct use of vegetable oil in diesel cycle engines is still problematic. Studies performed with various vegetable oils showed that the direct combustion causes excess of carbonization of the injectors, combustion chamber and the exhaust tubing, and also increase the struggle of the injection, contamination of the lubricant oil, among other problems (KRATZEISEN \& MÜLLER, 2010; AGARWAL et al., 2010; PAULSEN et al., 2011; ACHARYA et al., 2011).

The causes of these problems may be attributed to the occurrence of pyrolysis, polymerization and other reactions during the injection and combustion, caused by poor atomization. The high viscosity is the main reason for this problem. It may be related to the quality of the vegetable oil composition due to natural fatty acids, which can cause resistance to thermal decomposition such as unsaturated fatty acids and high molecular weight (RYAN III et al. 1984), as well as to processes due to which oils are subjected (cold pressing, hot pressing, degumming, etc.).

One alternative for reducing the viscosity of the oil is heating. Soybean oil, for example, when heated at $140^{\circ} \mathrm{C}$ reaches viscosities near to petrodiesel (RYAN III et al. 1984; BASINGER et al., 2010), being this viscosity still dependent on the oil composition, as the case of rice bran oil that at $120^{\circ} \mathrm{C}$ reaches practically the same viscosity of the petrodiesel at $40^{\circ} \mathrm{C}$ (ACHARYA et al, 2011).

In Brazil, there were some tests employing preheated $\left(57\right.$ and $\left.68^{\circ} \mathrm{C}\right)$ mixtures of soybean oil and petrodiesel $\left(10,30,50,70\right.$ and $100 \%$ soybean oil), and in all tests the temperature of $68^{\circ} \mathrm{C}$ had better performance than at $57^{\circ} \mathrm{C}$ and the mixture of $70 \%$ at $68^{\circ} \mathrm{C}$ was the best and better than petrodiesel (SCHLOSSER et al. 2007). In another test using sunflower oil without heating, was found, in both short and long duration, inferior performance when compared to petrodiesel. The long-term test (designed to last 200 hours) was suspended in 63 hours, because changes were observed in the lubricating oil temperature $\left(95\right.$ to $98^{\circ} \mathrm{C}$ with petrodiesel, to $\left.120^{\circ} \mathrm{C}\right)$ and differences in operating noise, besides the continuous loss of potency (MAZIERO et al. 2007).

Regarding the emission of particulate matter in the exhaust fumes, tests show that the different vegetable oils added to blends with petrodiesel and heating processes result in differentiated emissions. In studies using mixtures of turnip oil with petrodiesel with and without preheating in comparison with petrodiesel, showed that the opacities obtained for the preheated mixtures were inferior to the petrodiesel and for the mixtures without preheating were superior (HAZAR \& AYDIN, 2010). Other studies with mixtures of palm oil and coconut oil mixed with petrodiesel, without preheating, showed lower opacity values than petrodiesel (KALAM et al., 2011). In studies using mixtures of Sapindus mukorossi oil with petrodiesel and pure oil compared to petrodiesel, on average, all mixtures tested showed opacity inferior to petrodiesel and pure oil showed values superior to petrodiesel (MISRA \& MURTHY, 2011).

The aim of this study was to evaluate the useful life of some components of the lubricant and the emission of particulated matter from a diesel engine using fuel as a preheated mixture with 50\% of degummed soybean oil and 50\% commercially available diesel.

\section{MATERIAL AND METHODS}

The study was performed at the Laboratory of Agricultural Mechanization (Lama), of State University of Ponta Grossa (UEPG), located in Ponta Grossa city - Paraná (PR) state, in Brazil, and 
had, in the performing team, members of the highway concessionaire and the State University of Londrina (UEL), located in Londrina city - Paraná (PR) state, in Brazil.

To the development of the study it was used a Chevrolet S10 vehicle, year 2009, and the engine was according to the specifications of Table 1.

TABLE 1. Engine specifications.

\begin{tabular}{llll}
\hline Manufacturer & MWM-International & Aspiration & Intercooler Turbo \\
Model & SPRINT - 4.07TCE & Bore / Stroke & $93 / 103 \mathrm{~mm}$ \\
Cylinders numbers & 4 & Unitary displacement & $0700 \mathrm{~cm}^{3}$ \\
Cycle & Diesel - 4 times & Total displacement & $2.800 \mathrm{~cm}^{3}$ \\
Compression pressure & $1.3 \mathrm{MPa}$ & Compression rate & $17.8: 1$ \\
Combustion type & Direct Injection & $\begin{array}{l}\text { Maximum power } \\
\text { rotation }\end{array}$ & $\begin{array}{l}119.3 \mathrm{~kW} @ 3500 \\
\text { rotations min }\end{array}$ \\
Injection system & Electronic; Common & Maximum torque & $36.7 \mathrm{kgf} \mathrm{m}_{2} 2400$ \\
Injection maximum pressure & rail & & rotations $\mathrm{min}^{-1}$ \\
\hline
\end{tabular}

It was used as fuel (known in this study as OV50) a mixture of $50 \%\left(\mathrm{v} \mathrm{v}^{-1}\right)$ of soybean oil (Glycine max L.) degummed with metropolitan petrodiesel (5\% of biodiesel). This oil was extracted by the procedures used by the food industry and was used because of the quality technology already developed and standardized extraction.

Before the beginning of the test, the engine was fully rectified. We also made a conversion system developed by DELALIBERA (2009), in which was installed a second reservoir for OV50 fuel, with capacity of 220 liters, leaving the original tank for the use with petrodiesel. It was constructed a heating system coupled within the engine exhaust tubing, made with a $9.5 \mathrm{~mm}$ diameter tube ( $3 / 8$ inch) and comprised by a set of 14 coils of $60 \mathrm{~mm}$ diameter, contained in one tube of $76.2 \mathrm{~mm}$ ( 3 inches) diameter and $350 \mathrm{~mm}$ length. In this, the circulation of the mixture is forced by a fuel electric drive pump, as shown in Figure 1. The purpose of heating the OV50 fuel was to reduce its viscosity to bring it closer to the petrodiesel.

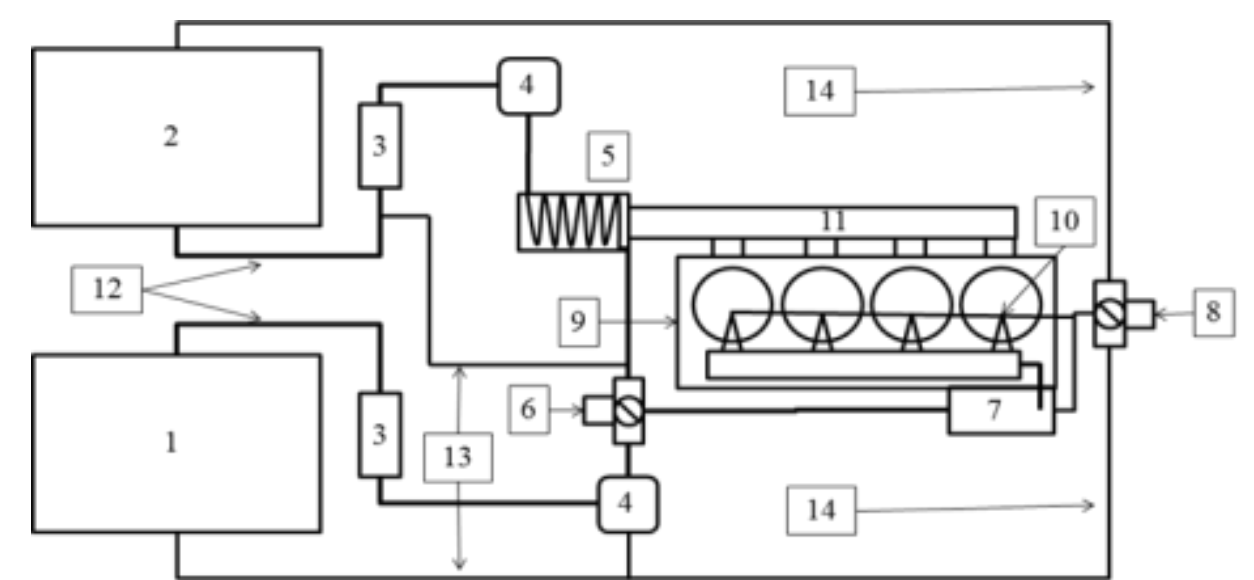

1 - Petrodiesel Tank; 2 - OV50 Tank; 3 - Feeder Electrical Bombs; 4 - Combustible Filters; 5 - Heating System; 6 - Conversion Valve of Feed; 7 - High Feeder Bomb; 8 - Conversion Valve of Feed Return; 9 - Engine; 10 - Injectors; 11 - Exhaust; 12 - Feeder Tubing; 13 - Tubing of Return of Feeder Bombs; 14 - Tubing of Return of Feed System.

FIGURE 1. Simplified diagram of the conversion system of petrodiesel to OV50.

The change of petrodiesel to OV50 is made by two three-way valves with electro-pneumatic actuation, one in the system of fuel admission of the engine and another in the return of the system, both activated simultaneously by a switch on the panel of the vehicle. 
The methodology of the study consists of the ignition of the engine always with diesel until the temperature of the liquid cooling reaches $70^{\circ} \mathrm{C}$ (the approximate temperature of the thermostatic valve opening) and, after this period, the switch of the panel is activated, changing the feeding to OV50 fuel. Before turning off the engine, the fuel is converted again to diesel over a period of about 10 minutes. This methodology was used to avoid problems with ignition (start) when the engine is cold, because of the high viscosity of the OV50 mixture when at ambient temperature cause pressure changes within the feeding tube of the injectors' nozzles (rail). When this pressure exceeds $145 \mathrm{MPa}$ a safety valve is triggered and depressurize the system by turning off the engine (working pressure: 32 to $135 \mathrm{MPa}$ at idle and full throttle), preventing the system from being damaged by excessive pressure. Moreover, the high viscosity can cause problems with fuel atomization.

The variables used to evaluate the performance of the engine when fed with OV50 were the compression pressure of the initial cylinders (after it has run for a period of 50 hours with petrodiesel for adjusting the internal moving parts) in relation to the final.

The injectors were evaluated in a bench test of injectors (Bosch EPS 200), using calibration fluid for diesel fuel injection system, with the following chemical composition: aliphatic hydrocarbons (open chain carbonic structure), mineral oil and anticorrosive additive (Castrol Ultra seni $4113^{\circledR}$ ). The performed tests included Seal (LT), Full Load (maximum volume in acceleration of maximum power at 3.500 rotations $\mathrm{min}^{-1}$ ) (VL), Pre-injection (VE), Idle Speed (LL), Emissions (injection volume at average acceleration; 2300 rotations $\min ^{-1}$ ) (EM), Return of oil at full load (RÜ) and Return of seal oil (amount of oil that returns by the return of injectors) (RLT). These procedures were used to evaluate the useful life of the injectors, being the patterns and nomenclature based on the specified by the manufacturer (Table 2).

It was also evaluated the degradation and contamination of the lubricant oil by wear of the moving parts and by fuel during the test period. The exchange was preceded according to the indicated by analysis (maximum limit specified by the manufacturer of 250 hours). To this engine are recommended 8 liters of lubricant with specification $15 \mathrm{~W} 40$ being composed of basic mineral oil and additives.

Fuel consumption was estimated by the amount of fuel used by the operating hours.

TABLE 2. Standards used in the tests with injectors nozzles.

\begin{tabular}{lcccc}
\hline \multicolumn{1}{c}{ Test step } & $\begin{array}{c}\text { Excitation } \\
\text { duration( }(\mu \mathrm{s})\end{array}$ & $\begin{array}{c}\text { Pressure } \\
(\mathrm{MPa})\end{array}$ & $\begin{array}{c}\text { Evaluation } \\
\text { time “t” }(\mathrm{s})\end{array}$ & $\begin{array}{c}\text { Nominal interval } \\
\left(\mathrm{mm}^{3} \mathrm{t}^{-1}\right)\end{array}$ \\
\hline Seal (LT) & 0 & 135 & 90 & 0 \\
Full Load (VL) & 1800 & 135 & 90 & 65.3 a 73.7 \\
Pre-injection (VE) & 160 & 80 & 90 & $0.2 \mathrm{a} 2.8$ \\
Idle Speed (LL) & 625 & 25 & 90 & 3.0 a 7.0 \\
Emissions (EM) & 500 & 80 & 90 & 16.4 a 22.4 \\
Return in full load (RÜ) & 1800 & 135 & 90 & 18.0 a 56.0 \\
Return in seal (RLT) & 0 & 135 & 90 & 0 a 70.0 \\
\hline
\end{tabular}

For determining the emission of particulate matter in the exhaust fumes, opacity tests were performed using Opacimeter (Bosch 96150706 number BEA reference), which determines the absorption of light coefficient ( $\mathrm{k}$ given in $\mathrm{m}^{-1}$ ) by the exhaust gases (smoke). The test was performed in a running engine with commercial diesel and OV50 with the following methodology: it awaits the engine enters a regime $\left(70^{\circ} \mathrm{C}\right.$ in liquid cooling) to conduct opacity readings on the respective fuel. The measurements were performed under free acceleration following the procedure according to NBR 13037 - Exhaust Gas Issued by Diesel Engine in Free Acceleration; Determination of Opacity - Test Method. The opacity limit index regulated by CONAMA 
Resolution No. $251 / 1999$ for the vehicle used is equal to $2.80 \mathrm{~m}^{-1}$. The opacity data were analyzed by Friedman with $5 \%$ probability of error, with four treatments (commercial diesel and initial OV50, commercial diesel and final OV50) with seven repetitions. This method was used due to the existence of dependence among these treatments and also by not presenting normality.

During the operation of the vehicle on the highway, 264 hours, we kept a cruising speed between 60 and $80 \mathrm{~km} \mathrm{~h}^{-1}$ with the engine rotation between 1800 and $2400 \mathrm{~min}^{-1}$, the oil pressure of the engine at 950 rotations $\min ^{-1}$ was $0.2 \mathrm{MPa}$ and the temperature of cooling system 70 to $86^{\circ} \mathrm{C}$.

\section{RESULTS AND DISCUSSION}

It was observed that the pressure in the feed of the injectors nozzles, with the engine at a rotation of maximum acceleration has not exceeded $132.8 \mathrm{MPa}$. This fact demonstrates that the system of preheating showed good outcomes.

During the test period, there were observed changes in pressure of the lubricating oil $(0.2$ to $0.6 \mathrm{MPa}$ of 950 to 3100 rotations $\mathrm{min}^{-1}$ ) and liquid cooling temperature $\left(73-86^{\circ} \mathrm{C}\right)$.

Regarding the compression pressure (Table 3), from the beginning to the end of the test it was observed that the first, second and third cylinders showed little increase in pressure, whereas only the fourth cylinder decreased. The increase in compression pressure of the first three cylinders demonstrates improved sealing rings, and in the case of the fourth cylinder the opposite occurred. These changes related to combustion, as carbonization, may change the sealing rings or limit the movement of the piston with the rings (prevents the ring to rotate in the gutter during operation of the engine or scuffing), reducing the compression ratio and causing damage to the cylinder (DELALIBERA, 2009).

TABLE 3. Compression pressure of the cylinders at times 0 and 264 hours.

\begin{tabular}{ccccc}
\hline $\begin{array}{c}\text { Time } \\
\text { (hours) }\end{array}$ & $\begin{array}{c}\text { 1st cylinder } \\
(\mathrm{MPa})\end{array}$ & $\begin{array}{c}\text { 2nd cylinder } \\
(\mathrm{MPa})\end{array}$ & $\begin{array}{c}\text { 3rd cylinder } \\
(\mathrm{MPa})\end{array}$ & $\begin{array}{c}\text { 4th cylinder } \\
(\mathrm{MPa})\end{array}$ \\
\hline 0 & 1.294 & 1.250 & 1.226 & 1.275 \\
264 & 1.368 & 1.348 & 1.304 & 1.121 \\
\hline Difference $(\%)$ & 5.7 & 7.8 & 6.4 & -12.1 \\
\hline
\end{tabular}

According to the injectors analisis (Table 4), it was observed that in time of 264 hours, except for the step of sealing test (LT), all injectors presented problems where, from this moment on, was not possible anymore to proceed engine ignition due to problems of injection. In the case of the third cylinder of the injector, the test was not performed in time 264 hours because it was not possible to obtain the required pressure in the injector to perform the test procedures. In RLT step of the injector 3 , the entire volume of test fluid injected came back by the return.

The results show that the fourth injector was also about to present the same problem, observed in the values presented in steps, where the volumes of return (RÜ and RLT) were high and outside the specified by the manufacturer (RÜ: 18.0 to 56.0 and RLT: 0 to 70.0), and the steps EM, VE and LL, were below the specified (Table 4), and for Idle Speed (LL), the loaded pressure in the injector was not enough to promote fuel injection at low pressures.

The problems in the injectors were caused by the wear of the internal components caused by changes in density, viscosity, lubrication, etc. That can compromise the components of the injection system through the cavitation, corrosion and accented wear. According to ARMAS et al. (2011), the probability of problems such as accented wear in injection systems of the common rail type is high, when altered the fuel properties compared to traditional fuel, because as they work with injection pressures and injection speeds and pre-injections very high, little wear on the elements damage the functioning of them. A fact which may explain the occurrence of bigger problems in the injectors 3 
and 4 , is that the admission entrance of the rail of fuel distribution is between the injector 1 and the relief valve on the extremity, so the OV50 mixture may have come to the last injectors with lower temperature.

TABLE 4. Evaluation of injectors by cylinder, in accordance with the step of test and working time, and the values of volume given in $\mathrm{mm}^{3}$ by the duration of the test $(\mathrm{t}=90 \mathrm{~s})$

\begin{tabular}{|c|c|c|c|c|c|c|c|c|c|c|c|}
\hline \multirow{2}{*}{$\begin{array}{l}\text { Test } \\
\text { Step }\end{array}$} & \multirow{2}{*}{$\mathrm{h}$} & $1^{\circ}$ & $2^{\circ}$ & $3^{\circ}$ & $4^{\circ}$ & \multirow{2}{*}{$\begin{array}{l}\text { Test } \\
\text { Step }\end{array}$} & \multirow{2}{*}{$\mathrm{h}$} & $1^{\circ}$ & $2^{o}$ & $3^{\circ}$ & $4^{\circ}$ \\
\hline & & & $\mathrm{mm}$ & $\mathrm{t}^{-1}$ & & & & \multicolumn{4}{|c|}{$\mathrm{mm}^{3} \mathrm{t}^{-1}$} \\
\hline \multirow{3}{*}{$\begin{array}{l}\text { Full Load } \\
\text { (VL) }\end{array}$} & 0 & 68.88 & 70.31 & 69.40 & 72.48 & \multirow{3}{*}{$\begin{array}{l}\text { Emissions } \\
\quad(\mathrm{EM})\end{array}$} & 0 & 19.68 & 20.54 & 19.13 & 19.84 \\
\hline & 34 & 65.26 & 71.54 & 70.91 & 69.88 & & 34 & 17.51 & 17.44 & 17.34 & 17.31 \\
\hline & 264 & 75.47 & 77.39 & - & 86.39 & & 264 & 23.00 & 23.20 & - & 16.20 \\
\hline \multirow{3}{*}{$\begin{array}{c}\text { Pre- } \\
\text { injection } \\
(\mathrm{VE})\end{array}$} & 0 & 2.66 & 2.57 & 2.34 & 2.46 & \multirow{3}{*}{$\begin{array}{l}\text { Return in } \\
\text { full load } \\
\text { (RÜ) }\end{array}$} & 0 & 27.37 & 20.07 & 30.21 & 27.37 \\
\hline & 34 & 1.90 & 2.22 & 2.92 & 2.49 & & 34 & 31.72 & 26.87 & 28.31 & 28.48 \\
\hline & 264 & 2.91 & 3.29 & - & 1.11 & & 264 & 77.69 & 76.98 & - & 291.51 \\
\hline \multirow{3}{*}{$\begin{array}{l}\text { Idle Speed } \\
\text { (LL) }\end{array}$} & 0 & 4.14 & 4.95 & 4.20 & 4.64 & \multirow{3}{*}{$\begin{array}{l}\text { Return } \\
\text { in seal } \\
\text { (RLT) }\end{array}$} & 0 & 7.22 & 3.36 & 3.20 & 4.24 \\
\hline & 34 & 1.12 & 3.14 & 3.21 & 1.94 & & 34 & 5.09 & 3.46 & 6.08 & 7.92 \\
\hline & 264 & 6.80 & 4.76 & - & 0 & & 264 & 31.72 & 26.53 & 403.45 & 248.46 \\
\hline
\end{tabular}

The changes in compression pressure of the fourth cylinder (Table 3) compared to time zero of the test may be caused by a deficiency of injection of the injector 4 (Table 4). Regarding the injection disability on mean rotation (EM), in Idle Speed (LL) and Pre-injection (LV), which may have caused the wear of the rings or carbonization disability on the part between the ring and the piston gutter, carbonization that favor the sealing rings, or even excessive carbonization, promoting the scuffing of it.

To the lubricant oil, samples were taken at zero (0), 50 and 253 hours of operation, according to the change time recommended by the manufacturer (Table 5). There were no quantitative differences in the crankcase oil.

In 253 hours versus time zero, there was approximately $18 \%$ reduction in viscosity at $100^{\circ} \mathrm{C}$ which, according to CHEN and HSU (2003), may be an effect of their own thermal degradation. Combustion products, such as $\mathrm{SO}_{\mathrm{x}}, \mathrm{NO}_{\mathrm{x}}, \mathrm{CO}_{\mathrm{x}}, \mathrm{H}_{2} \mathrm{O}$ and $\mathrm{H}_{2} \mathrm{SO}_{4}$ as well as incomplete combustion can reduce the viscosity (PORTE, 2008). According to SNOOK (1968), decreases in viscosity at $100^{\circ} \mathrm{C}$ up to $25 \%$ (10.73 cSt for the lubricant used) are acceptable. These values are questionable, i.e., depend on the technology used in the engine, the working regime, the aspirated air quality, etc. and may vary from values very rigorous, $5 \%$, to even more flexible values as 15 to $25 \%$ of viscosity reduction at $100^{\circ} \mathrm{C}$ in the moment of change in relation to the initial (ESSO 1970).

Table 5 shows the quantification of elements found in lubricant oil in accordance with the working time. For SNOOK (1968), ESSO (1970), ASSEFF (1975) and PILLIPS et al. (1979), the most concerning data are those regarding to the contents of constituent elements of the moving parts, such as $\mathrm{Fe}, \mathrm{Cu}, \mathrm{Cr}, \mathrm{Al}, \mathrm{Pb}$ and $\mathrm{Sn}$, which are direct indicators of wear. The authors comment on the limiting content or indicators of oil change or accented wear of moving parts, such as $70 \mathrm{ppm}$ for $\mathrm{Fe}$, where values around $36 \mathrm{ppm}$ may be considered acceptable. For $\mathrm{Cu}, \mathrm{Cr}, \mathrm{Al}, \mathrm{Pb}$ and $\mathrm{Sn}$ at time 253 hours, the values found were inferior to those limit values of 19.0, 6.4, 17.0, 30.0 and 4.0 ppm, respectively. 
Elements such as Si and part of Al may be from the air contaminants from deficiency of the filtration system. According to ASSEFF (1975) Si contents above $16 \mathrm{ppm}$ are worrying. Interesting to note that the analysis of the new lubricant on this test showed high content of $\mathrm{Si}$. Other contaminants that are of concern regarding the life of the lubricant are the $\mathrm{Cu}$ and $\mathrm{Ni}$, which according to YAWAR (2010), have catalytic effect on the processes of oxidation of the lubricant, however, the author does not comment concentrations of concern.

Among other elements, it may not be attributed only the contamination by products of the fuel and the wear of moving parts, since according to SÁGI et al. (2008), elements such as $\mathrm{Ca}, \mathrm{P}, \mathrm{Zn}$, $\mathrm{Mo}, \mathrm{Na}, \mathrm{Ag}, \mathrm{B}, \mathrm{Ba}, \mathrm{Mg}$, Ti and $\mathrm{V}$, may be present in the lubricant composition as additives which perform various functions within the engine.

Among the items showed in Table 5, according to DELALIBERA (2009) for the case of using vegetable oils as fuels, the ones that draw attention are $\mathrm{Mg}, \mathrm{P}$ and $\mathrm{K}$ and may be present in the fuel composition. In this case, the last one was present in the analysis of lubricant with 253 hours. Another important quality indicator is the number of overall basicity (TBN) that according to DAM et al. (1997) indicates the capabilities of the alkaline reserve of the lubricant that protects the internal engine components from oxidation and corrosion. According to this author, TBN value of less than half of the initial (3.61 for the used lubricant) is an indicator for changing the lubricant. In general, exchange of lubricating preceded in time 253 hours (indicated by the manufacturer) was appropriate and not changed by the fuel used, because this time the Si contents found in the sample were considered high.

TABLE 5. Results of lubricant oil analysis in accordance with working time.

\begin{tabular}{|c|c|c|c|c|c|c|c|c|c|}
\hline \multirow{2}{*}{ Parameters } & \multirow{2}{*}{ uni. ${ }^{*}$} & \multicolumn{3}{|c|}{ Time (h) } & \multirow{2}{*}{ Parameters ${ }^{6}$} & \multirow{2}{*}{ uni. } & \multicolumn{3}{|c|}{ Time $(\mathrm{h})$} \\
\hline & & 0 & 57 & 253 & & & 0 & 57 & 253 \\
\hline Visc. $40{ }^{\circ} \mathrm{C}^{1}$ & $\mathrm{cSt}$ & 91.13 & 75.38 & 73.19 & Aluminium (Al) & ppm & 1.52 & 5.23 & 6.53 \\
\hline Visc. $100^{\circ} \mathrm{C}^{1}$ & $\mathrm{cSt}$ & 14.31 & - & 11.70 & Copper $(\mathrm{Cu})$ & ppm & 0.10 & 2.78 & 7.01 \\
\hline Index of Visc. ${ }^{1}$ & - & 163 & - & 135 & Chromium (Cr) & ppm & 0.10 & 1.96 & 5.23 \\
\hline $\mathrm{TBN}(\mathrm{KOH} / \mathrm{g})^{2}$ & $\mathrm{mg}$ & 7.22 & 5.07 & 5.71 & $\operatorname{Iron}(\mathrm{Fe})$ & ppm & 0.10 & 8.97 & 33.03 \\
\hline Density & $\mathrm{g} \mathrm{cm}^{-3}$ & 0.857 & - & - & Silicium (Si) & ppm & 65.14 & 11.63 & 15.55 \\
\hline Dilution & $\%$ & 0 & 2.0 & 0.5 & Lead $(\mathrm{Pb})$ & ppm & 0.10 & 0.82 & 0.30 \\
\hline Swindling & $\%$ & 0 & 0.1 & 0.21 & Zinc (Zn) & ppm & 1156 & 1216 & 993.5 \\
\hline Precipitation $^{3}$ & $\%$ & 0 & 0.1 & 0.25 & $\operatorname{Tin}(\mathrm{Sn})$ & $\mathrm{ppm}$ & 0.10 & 0.10 & 2.93 \\
\hline Insol. Pent ${ }^{4}$ & $\%$ & 0 & 0.02 & 0.05 & Molybdenum (Mo) & ppm & 0.10 & 0.10 & 0.05 \\
\hline Contamination & $\%$ & 0 & 0.2 & - & Nickel (Ni) & ppm & 0.10 & 0.10 & 0.05 \\
\hline Dispersity & - & 0 & 92 & - & Calcium (Ca) & ppm & 2062 & 2262 & 2452.5 \\
\hline Weighed loss & - & 0 & 2 & - & Sodium (Na) & ppm & 0.10 & 0.10 & 1.86 \\
\hline Water & ppm & 600 & 0 & 0 & Silver (Ag) & ppm & 0.10 & 0.10 & 0.05 \\
\hline Effulgence point & ${ }^{\circ} \mathrm{C}$ & - & - & 206 & Boron (B) & ppm & 0.10 & 0.10 & 0.55 \\
\hline IPF & - & 10 & 13 & 21 & Barium (Ba) & ppm & 0.28 & 0.10 & 0.14 \\
\hline Oxidation $\mathrm{FS}^{5}$ & abs $\mathrm{mm}^{-2}$ & - & 8.94 & 12.04 & Magnesium (Mg) & ppm & 197.8 & 221.5 & 173.7 \\
\hline Nitration FS ${ }^{5}$ & abs $\mathrm{mm}^{-2}$ & - & 7.24 & 6.35 & Manganese (Mn) & ppm & 0.10 & 0.45 & 0.10 \\
\hline \multirow[t]{4}{*}{ Sulfation $\mathrm{FS}^{5}$} & abs $\mathrm{mm}^{-2}$ & - & 18.99 & 14.25 & Phosphorus (P) & ppm & 911.8 & 936.9 & 1008.5 \\
\hline & & & & & Titanium (Ti) & ppm & 0.10 & 0.10 & 0.05 \\
\hline & & & & & Vanadium (V) & ppm & 0.10 & 0.11 & 0.05 \\
\hline & & & & & Potassium (K) & ppm & - & - & 4 \\
\hline
\end{tabular}

${ }^{1}$ ASTM D455; ${ }^{2}$ ASTM D4739; ${ }^{3}$ ASTM D91; ${ }^{4}$ ASTM D4055; ${ }^{5}$ ASTM E2412; ${ }^{6}$ ASTM D4951;*unity 
Also regarding to the useful life of the lubricant, DELALIBERA (2009) found reduction of $60 \%$ to $70 \%$ when used engines with mechanical injection system, in this case, it is believed that the electronic injection system favors combustion, because of the larger injection pressures and injection speeds added to the pre-injections. However, the test was terminated at 264 hours time due to failures in the injection system.

In opacity tests with commercial diesel compared to the OV50 mixture (Table 6 and Figure 2 ), it was observed variations in the emissions of particulate matter over time of use. The commercial diesel at time zero (PD-T0) was statistically different presenting levels of opacity smaller than diesel in time 253 hours (PD-T253) and did not present difference of the OV50-T0 test. The OV50-T253 presented difference from OV50 and PD at T0, however, no statistically significant difference in PD-T253. The marked line in Figure 2 still indicates the maximum limit set by legislation $\left(2.8 \mathrm{~m}^{-1}\right)$, the evaluation of OV50-T253 would reprove the engine, even this evaluation not differing from the PD-T253 evaluation. CANAKCI et al. (2009) in a test of short duration in a dynamometric bench with a Diesel engine fueled with sunflower oil preheated at $75^{\circ} \mathrm{C}$, found that the opacity values and hydrocarbon emissions over load were lower than when used petrodiesel. OZSEZEN et al. (2009) also found similar results regarding to opacity of emissions when using methyl esters of rapeseed and palm, these being $67.65 \%$ and 47.96 inferior compared to petrodiesel.

TABLE 6. Friedman's analysis of opacity with commercial petrodiesel (PD) and the blend (OV50) in times T0 and T253.

\begin{tabular}{lcccc}
\hline & PD-T0 & OV50-T0 & PD-T253 & OV50-T253 \\
\hline Sum of Ranks & 8.0 & 13.0 & 22.0 & 27.0 \\
Mean of Ranks & 1.14 & 1.86 & 3.14 & 3.86 \\
Standard deviation (k) & 0.03 & 0.32 & 0.07 & 1.23 \\
Mean (k) & 0.42 & 0.86 & 1.25 & 3.29 \\
Median (k) & 0.41 & 0.98 & 1.26 & 3.81 \\
\hline Difference of Ranks & $\mathrm{a}$ & $\mathrm{ab}$ & $\mathrm{bc}$ & $\mathrm{c}$ \\
\hline
\end{tabular}

Friedman; $\mathrm{p}<0,05$

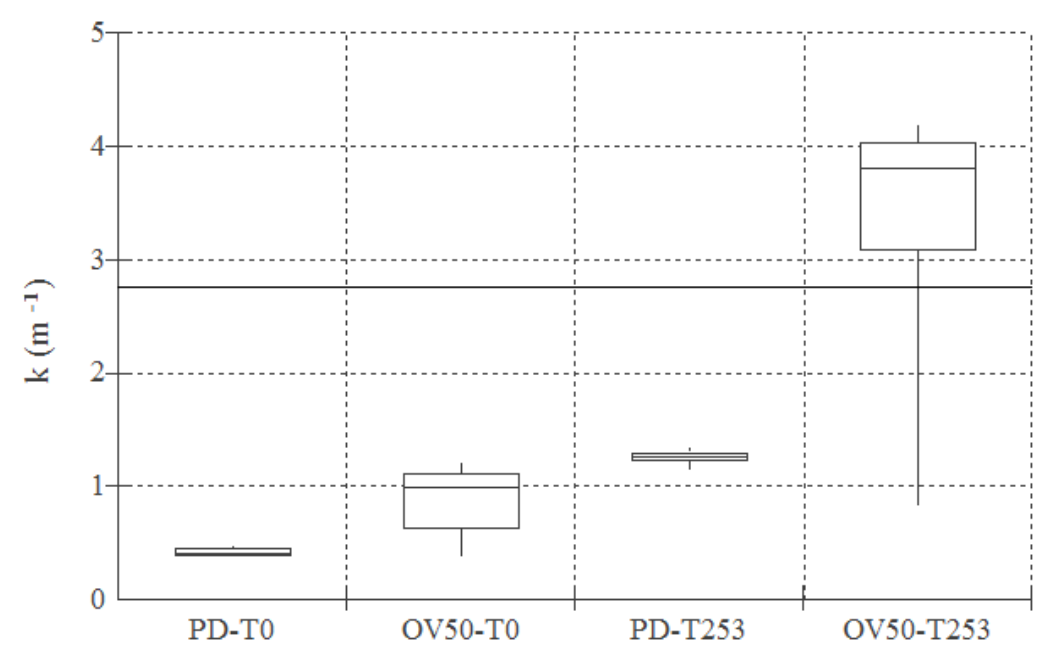

FIGURE 2. Box-plot of the medians and quartiles for the opacity to petrodiesel (PD) and the blend (OV50) at times T0 and T253 hours of work.

Rising levels of opacity from time zero (T0) for time 253 hours, may be attributed to failures in the injection system, as discussed above, that after 264 hours of operation, had serious failures. 
Regarding to consumption, this was on average $10.2 \%$ higher than the results obtained with the vehicle moving with commercial diesel, which is expected because the calorific value of vegetable oil is less than the petrodiesel.

\section{CONCLUSIONS}

The fuel evaluated reduced life of the engine injectors.

The common rail system was unstable to changes in fuel.

The lubricant oil showed reduced contamination by products of pyrolysis.

With 264 hours of operation, there was an increase in emission of particulate matter (opacity) which may be attributed to failures in the injection system.

\section{ACKNWOLEGMENTS}

To CAPES for the concession of the scholarship.

To the Integrated Concessionaires of Highways - CCR/Rodonorte for providing the vehicle and the necessary financial resources for the development of the study.

Retimaq - Machinery Recondition for ceding space and physical infrastructure and technical expertise to the realization of the study.

\section{REFERENCES}

ACHARYA, S.K.; SWAIN, R.K.; MOHANTY, M.K. The Use of Rice Bran Oil as a Fuel for a Small Horse-power Diesel Engine. Energy Sources, Part A, Laramie, v. 33, p. 80-88, 2011.

AGARWAL, A.K.; GUPTA, T.; KOTHARI, A. Toxic potential evaluation of particulate matter emitted from a constant speed compression ignition engine: A comparison between straight vegetable oil and mineral diesel. Aerosol Science and Technology, Philadelphia, v. 44, p. 724-733, 2010.

ARMAS, O.; MARTÍNEZ-MARTÍNEZ, S.; MATA, S. Effect of an ethanol-biodiesel-diesel blend on a common rail injection system. Fuel Processing Technology, Philadelphia, v. 92, p. 2145-2153, 2011.

ASSEFF, P.A. The lubizol corporation ESSO: Analisis de aceite usaso - SU significado. Instituto Americano del Petróleo, 1975. v. 16.

BASINGER, M.; REDING, T.; WILLIAMS, C.; LACKNER, K.S.; MODI, V. Compression ignition engine modifications for straight plant oil fueling in remote contexts: Modification design and short-run testing. Fuel, Nottingham, v. 89, p. 2925-2938, 2010.

CHEN, C.-I; HSU, S.M. Chemical kinetics model to predict lubricant performance in a diesel engine. Part I: Simulation methodology. Tribology Letters, Zürich, v.14, n.2, p. 83-90, 2003.

CANACKI, M.; OZSEZEN, A.N.; TURKCAN, A. Combustion analysis of preheated crude sunflower oil in an IDI diesel engine. Biomass and Bioenergy, Aberdeen, n. 33, p. 760-767, 2009.

DAM, W.; BRODERICK, D.H.; FREERKS, R.L.; SMALL, V.R.; WILLIS, W.W. TBN Retention are we missing the point? Diesel engine lubricant characterization using multiple used oil analyses, SAE Paper, Washington, n. 970000972950, 1997.

DELALIBERA, H.C. Utilização do Óleo de Girassol como Combustível em Unidade de Potência Monocilindro Ciclo Diesel. 2009. 77 f. Disertação (Mestrado em Agronomia) - Universidade Estadual de Ponta Grossa, Ponta Grossa, 2009.

ESSO. Boletim de Informações Técnicas: limites de uso, avaliação dos óleos de cárter. Esso Brasileira de Petróleo, v.1, p.42, 1970. 
HAZAR, H.; AYDIN, H. Performance and emission evaluation of a CI engine fueled with preheated raw rapeseed oil (RRO) diesel blends. Applied Energy, Stockholm, v. 87, p. 786-790, 2010.

KALAM, M.A.; MASJUKI, H.H.; JAYED, M.H.; LIAQUAT, A.M. Emission and performance characteristics of an indirect ignition diesel engine fuelled with waste cooking oil. Energy, Aalborg, v. 36, p. 397-402, 2011.

KRATZEISEN, M.; MÜLLER, J. Prediction of deposit formation during combustion of Jatropha oil from standard quality parameters. Fuel, Nottingham, v. 89, p. 2769-2774, 2010

MAZIERO, J.V.G.; CORRÊA, I.M.; ÚNGARO, M.R.; BERNARD, J.A.; STORINO, M. Desempenho de um motor diesel com óleo bruto de girassol. Revista Brasileria de Agrociência, Pelotas, v.13, n.2, p.249-255, abr-jun, 2007.

MISRA, R.D.; MURTHY, M.S. Performance, emission and combustion evaluation of soapnut oildiesel blends in a compression ignition engine. Fuel, Nottingham, v. 90, p. 2514- 2518, 2011.

OZSEZEN, A.N; CANAKCI, M.; TURKCAN, A.; SAYIN, C. Performance and combustion characteristics of a DI diesel engine fuelled with waste palm oil and canola oil methyl esters. Fuel, Nottingham, n. 88, p. 629-636, 2009.

PAULSEN, H.M.; WITCMANN, V.; SCHUEMANN, U., RICHTER B. Use of straight vegetable oil mixtures of rape and camelina as on farm fuels in agriculture. Biomass and Bioenergy, Aberdeen, v. 35, p. 4015-4024, 2011.

PILLIPS, O.H.; LANE, P.D.; SHADDAY, M.C. Diesel engine wear with spin on bypass lube oil filters. In: CONGRESS AND EXPOSITION COBO HAIL, 1979., Detroit. Proceedings... (SAE Technical Paper Series).

PORTE, F.A. Biodiesel de girassol em microtratores monocilíndricos: emissões, consumo específico e conseqüências de seu uso para o motor. 2008. Dissertação (Mestrado) - Universidade de Santa Cruz do Sul, 2008.

RYAN III, T.W.; DODGE, L.G.; CALLAHAN, T.J. The effects of vegetable oil properties on injection and combustion in two different diesel engines. JAOCS, Champaign, v.61, n.10, p.16101619, 1984.

SAGI, R.; MISCOLCZI, N.; BARTHA, L.; HALMOS, P. Elemental analysis of engine oils using energy dispersive $\mathrm{x}$-ray fluorescence spectroscopy (EDXRFS) and inductively coupled plasma atomic emission spectroscopy (ICP-AES). Petroleum \& Coal, Bratislava, v.50, n.1, p.1-10, 2008.

SCHLOSSER, J.F.; MACHADO,P.R.M.; CAMARGO,M.N.. Desempenho de misturas préaquecidas de óleo de soja cru e diesel como combustível para motores agrícolas. Ciência Rural, Santa Maria, v.37, n.5, 2007.

SNOOK, W.A. Lubrificação: uma publicação técnica dedicada a escolha e uso de lubrificantes; análises de óleos usados de motores. Texaco Brasil, São Paulo, v.54, n. 9, 1968.

YAWAR, W. Determination of Wear Metals in Lubricating Oils by Flame Atomic Absorption Spectrophotometry. Journal of Analytical Chemistry, Moscow, v. 65, n. 5, p. 489-491, 2010. 